\title{
Adoption of improved chilli (Capsicum annum L.) cultivation technology among the farmers of district Chittorgarh
}

\author{
R.S. Rathore*, R.L. Solanki and B.S. Kumpawat \\ Krishi Vigyan Kendra, Chittorgarh \\ Maharana Pratap University of Agriculture and Technology, Udaipur -313001 \\ *Email: drrathorers@gmail.com
}

\begin{abstract}
Chilli (Capsicum annum L.) is one of the important commercial crop of Rajasthan. The present study was conducted in six villages in Gangrar tehsil of district Chittorgarh. To the selection of respondents, a comprehensive list of all the chilli growers were prepared from selected villages. The production of vegetables is largely in the hands of small and marginal farmers and productivity is low as compared to other countries. The major reasons are lack of high yielding varieties, pest and diseases infestation, losses due to weed emergence, post harvest handling etc. The findings indicated that majority of the farmers $(65.00 \%)$ had medium level of adoption regarding improved chilli cultivation technology, while 23.33 and 11.67 per cent respondents had low and high adoption level, respectively. The study further indicated that practice wise adoption of the respondents was more in time of sowing followed by irrigation, land preparation, seed rate, seed treatment, harvesting and drying, whereas less adoption level was recorded by the farmers in practice like high yielding varieties, weed management and plant protection.
\end{abstract}

Keywords: chilli, cultivation, technology, vegetables, Chittorgarh.

Paper cited: Rathore, R.S., Solanki, R.L. and Kumpawat, B.S. (2016). Adoption of improved chilli (Capsicum annum L.) cultivation technology among the farmers of district Chittorgarh. South Asian Journal of Food Technology and Environment, 2(2): 381-383.

\section{Introduction}

Chilli(Capsicum annum L.) also known as "wonder spice" is one of the important commercial crop of Rajasthan. It is grown almost throughout the state. The major chilli growing districts are Jodhpur, Nagour, Bhilwara, Chittorgarh, Kota and Bundi etc. Chilli is known from pre-historic times in Peru and they are believed to have originated in the tropical America. Chilli is an indispensable condiment and used in the daily diet of every Indian household in one or other form. Chillies are used as whole pods, dry powder, in pickles and stuffed. Pungency in chillies is due to alkaloid capsaicin. The red colour of chillies is due to the presence of pigment capsanthin. Chilli can be grown on all type of soil from light sandy to heavy clay. It is very sensitive to water logging. The production of vegetables in India is largely in the hands of small and margin farmers and productivity is below the level as prevailing is other countries. The level of productivity is attributed to lack of high yielding varieties, pest and diseases infestation, losses due to weed emergence, post harvest handling etc. Keeping this in view, the present study was carried out with the specific objective i.e. to measure the extent of adoption of improved chilli cultivation technology by the farmers.

\section{Materials and methods}

The present study was conducted in Gangrar tehsil of district Chittorgarh. This area is famous for vegetable cultivation particularly chilli. Total six villages were selected for study. For selection of respondents, a comprehensive list of all the chilli growers were prepared from selected villages. The listed farmers of each villages were categories into three categories namely $(<1$ ha land), small (1-2 ha land) and large ( $>2$ ha land).Then proportionate sample from each category was drawn randomly to have a total sample size 60 chilli growers. Data were collected by personal interview technique through suitable 
structured schedule. Thereafter data were tabulated, analyzed and inferences were drawn in light of the objective.

\section{Results and Discussion}

Distribution of respondents according to their overall adoption: To get an overall view of the adoption level, the chilli growers were grouped in to low, medium and high adoption level on the basis of calculated mean and standard deviation of the obtained adoption score by the respondents. Data pertaining to distribution of respondents on the basic of adoption was presented in Table 1. It reveals that majority of the respondents $(65.00 \%)$ fall in the medium level of adoption group whereas 23.33 per cent had low adoption level and only 11.67 per cent chilli growers had high level of adoption of improved chilli cultivation technology. Further, result indicated that more number of marginal farmers and small farmers had low level of adoption as compared to large farmers.

The adoption level of large farmers was higher than small and marginal farmers. It might be due to reason that level of large farmers was comparatively higher than the marginal and small farmers. Another reason behind results may be that majority of the larger farmers were educated, resourceful and had large land holdings size.The result confirms the findings of Desai et al. (1996) in cumin crops, Poonia and Dangi (1997)in ginger crop, Meena et al., (2006) in Ajwain crop and Jaitawat et al.,(2008) in fennel crop. In accordance with the findings, it is recommended that all the categories of farmer's specially marginal and small farmers should be motivated and encouraged to enhance the level of adoption through well planned follow up action by extension agencies/Krishi Vigyan Kendras etc.

Table 1: Distribution of respondents on the basis of adoption level of improved chilli cultivation

\begin{tabular}{|c|c|c|c|c|c|c|c|c|c|}
\hline \multirow[t]{2}{*}{ S. No } & \multirow[t]{2}{*}{$\begin{array}{l}\text { Level of } \\
\text { adoption }\end{array}$} & \multicolumn{2}{|c|}{$\begin{array}{c}\text { Marginal } \\
\text { farmers }\end{array}$} & \multicolumn{2}{|c|}{ Small farmers } & \multicolumn{2}{|c|}{ Large farmers } & \multicolumn{2}{|c|}{ Total } \\
\hline & & $\mathbf{F}$ & $\%$ & $\mathbf{F}$ & $\%$ & $\mathbf{F}$ & $\%$ & $\mathbf{F}$ & $\%$ \\
\hline 1. & Low $(<25.78)$ & 06 & 30.00 & 05 & 25.00 & 03 & 15.00 & 14 & 23.33 \\
\hline 2. & $\begin{array}{l}\text { Medium } \\
(25.78-35.98)\end{array}$ & 12 & 60.00 & 13 & 65.00 & 14 & 70.00 & 39 & 65.00 \\
\hline 3. & High $>35.98$ & 02 & 10.00 & 02 & 10.00 & 03 & 15.00 & 07 & 11.67 \\
\hline & Total & 20 & 100.00 & 20 & 100.00 & 20 & 100.00 & 60 & 100.00 \\
\hline
\end{tabular}

$\mathrm{F}=$ Frequency, $\%=$ Percentage

Practice wise adoption of advancechilli cultivation technology among the farmers: Practice wise adoption of advance chilli cultivation technology by the marginal, small and large farmers was worked out. For this purpose mean per cent scores were calculated. The results about the same have been presented in Table 2. A close examination of data (Table 2) revealed that maximum adoption level was reported in sowing time practice with mean per cent score 69.78. This was followed by the practices like irrigation, land preparation, seed rate, seed treatment and harvesting \& drying with the 54.03, 50.34, 45.91,
45.14, and 43.55\% mean score, respectively. While, practices like manure \& fertilizers, soil treatment, spacing, high yielding varieties, weed management and plant protection were having less adoption level with mean per cent scores38.02, 32.42, 23.08, 14.18, 6.15 and 5.19, respectively. A close observation of the Table 2 shows that the adoption level was higher in case of the large farmers than marginal and small farmers in major areas of chilli cultivation technology. The large farmers had higher adoption level due to their better economic condition, higher education level so they availed 
desirable facilities that small and marginal farmers were deprived off. Therefore, it is suggested that marginal and small farmers should be well equipped and persuaded strategically for increasing the adoption level of improved technology of chilli cultivation. Front line demonstrations may also be conducted on the fields of marginal and small farmers by the KVK. The finding is similar with the findings of Puranik and Verma (1992) in sweet potato and Jaitawat et al., (2008) in fennel crop.

Table 2: Extent of adoption of improved chilli production practices by the respondents

\begin{tabular}{|c|l|c|c|c|c|}
\hline S.No. & Improved practices & $\begin{array}{c}\text { Marginal } \\
\text { farmers MPS }\end{array}$ & $\begin{array}{c}\text { Small } \\
\text { farmers }\end{array}$ & $\begin{array}{c}\text { Large farmers } \\
\text { MPS }\end{array}$ & Total MPS \\
\hline 1. & High yielding varieties & 12.95 & 13.35 & 16.25 & 14.18 \\
\hline 2. & $\begin{array}{l}\text { Soil and land } \\
\text { preparation }\end{array}$ & 46.17 & 50.35 & 54.52 & 50.34 \\
\hline 3. & Soil treatment & 32.15 & 30.85 & 34.27 & 32.42 \\
\hline 4. & Seed treatment & 28.75 & 35.17 & 71.52 & 45.14 \\
\hline 5. & Seed rate & 52.65 & 37.73 & 47.36 & 45.91 \\
\hline 6. & Time of sowing & 67.75 & 70.25 & 71.36 & 69.78 \\
\hline 7. & Recommended spacing & 22.47 & 20.07 & 26.72 & 23.08 \\
\hline 8. & $\begin{array}{l}\text { Manure \& fertilizer } \\
\text { application }\end{array}$ & 32.65 & 39.15 & 42.27 & 38.02 \\
\hline 9. & Irrigation & 45.48 & 52.27 & 64.35 & 54.03 \\
\hline 10. & Weed management & 4.85 & 5.65 & 7.95 & 6.15 \\
\hline 11. & $\begin{array}{l}\text { Plant protection } \\
\text { measures }\end{array}$ & 4.15 & 7.45 & 3.98 & 5.19 \\
\hline 12. & Harvesting and drying & 43.65 & 40.45 & 46.56 & 43.55 \\
\hline
\end{tabular}

\section{Conclusion}

The findings indicated that majority of the farmers $(65.00 \%)$ had medium level of adoption regarding improved chilli cultivation technology, while 23.33 and 11.67 per cent respondents had low and high adoption level, respectively. The study further indicated that practice wise adoption of the respondents was more in time of sowing followed by irrigation, land preparation, seed rate, seed treatment and harvesting \& drying, whereas less adoption level was recorded by the farmers in practice like high yielding varieties, weed management and plant protection.

\section{References}

1. Desai, C.P., Pandey, D.N., Patel, M.R. and Patel, A.A. (1996). Farmer's satisfaction with adoption of cumin cultivation. Gujarat
Agricultural University Research Journal, 21 (2): $72-75$

2. Jaitawat, G.S., Bhimawat, B.S. and Sisodia, S.S. (2008). Adoption of improved fennel cultivation technology by the farmers in Sirohi district of Rajasthan. Rajasthan Journal of Extension Education, 16: 158 161.

3. Meena, R., Sharma, C., Sharma, V.P., Bhimawat, B.S. and Dadheech, B.S. (2006). Adoption of improved Ajwain production practices among the farmers of Dungla Tehsil in Chittorgarh district of Rajasthan. Rajasthan Journal of Extension Education, 14 : $47-51$

4. Poonia, P.P. and Dangi, K.L.(1997). Adoption behavior of ginger growers. Maharashtra Journal of Extension Education, 16: 116-119.

5. Puranik, R.P. and Verma, P.R. (1992). Adoption of sweet potato technology. Indian Journal of Extension Education, 28: 114-116. 